\title{
Coagulopathy and Thrombosis as a Result of Severe COVID-19 Infection: A Microvascular Focus
}

\author{
Upendra K. Katneni ${ }^{1}$ Aikaterini Alexaki ${ }^{2}$ Ryan C. Hunt ${ }^{2}$ Tal Schiller ${ }^{3}$ Michael DiCuccio ${ }^{4}$ \\ Paul W. Buehler ${ }^{1}$ Juan C. Ibla ${ }^{5}$ Chava Kimchi-Sarfaty ${ }^{2}$
}
${ }^{1}$ Department of Pediatrics, The Center for Blood Oxygen Transport and Hemostasis, University of Maryland School of Medicine, Baltimore, Maryland, United States
2 Hemostasis Branch, Division of Plasma Protein Therapeutics, Office of Tissues and Advanced Therapies, Center for Biologics Evaluation \& Research, U.S. FDA, Silver Spring, Maryland, United States
3 Diabetes, Endocrinology and Metabolic Disease Unit, Kaplan Medical Center, Rehovot, Israel
${ }^{4}$ National Center of Biotechnology Information, National Institutes of Health, Bethesda, Maryland, United States
${ }^{5}$ Division of Cardiac Anesthesia, Department of Anesthesiology, Perioperative and Pain Medicine, Boston Children's Hospital and Harvard Medical School, Boston, Massachusetts, United States

Address for correspondence Chava Kimchi-Sarfaty, Hemostasis Branch, Division of Plasma Protein Therapeutics, Office of Tissues and Advanced Therapies, Center for Biologics Evaluation \& Research, US FDA, Silver Spring, MD 20993, United States

(e-mail: Chava.kimchi-sarfaty@fda.hhs.gov).

Thromb Haemost 2020;120:1668-1679.

\begin{abstract}
Keywords

- COVID-19

- thrombosis

- inflammation

- ADAMTS-13

- von Willebrand factor

Coronavirus disease of 2019 (COVID-19) is the clinical manifestation of the respiratory infection caused by severe acute respiratory syndrome coronavirus 2 (SARS-CoV-2). While primarily recognized as a respiratory disease, it is clear that COVID-19 is systemic illness impacting multiple organ systems. One defining clinical feature of COVID-19 has been the high incidence of thrombotic events. The underlying processes and risk factors for the occurrence of thrombotic events in COVID-19 remain inadequately understood. While severe bacterial, viral, or fungal infections are well recognized to activate the coagulation system, COVID-19-associated coagulopathy is likely to have unique mechanistic features. Inflammatory-driven processes are likely primary drivers of coagulopathy in COVID-19, but the exact mechanisms linking inflammation to dysregulated hemostasis and thrombosis are yet to be delineated. Cumulative findings of microvascular thrombosis has raised question if the endothelium and microvasculature should be a point of investigative focus. von Willebrand factor (VWF) and its protease, a disintegrin and metalloproteinase with a thrombospondin type 1 motif, member 13 (ADAMTS-13), play important role in the maintenance of microvascular hemostasis. In inflammatory conditions, imbalanced VWF-ADAMTS-13 characterized by elevated VWF levels and inhibited and/or reduced activity of ADAMTS-13 has been reported. Also, an imbalance between ADAMTS-13 activity and VWF antigen is associated with organ dysfunction and death in patients with systemic inflammation. A thorough understanding of VWF-ADAMTS-13 interactions during early and advanced phases of COVID-19 could help better define the pathophysiology, guide thromboprophylaxis and treatment, and improve clinical prognosis.
\end{abstract}

received

May 14, 2020

accepted after revision

July 14,2020 (c) 2020. Thieme. All rights reserved. Georg Thieme Verlag KG,

Rüdigerstraße 14,

70469 Stuttgart, Germany
DOI https://doi.org/

10.1055/s-0040-1715841. ISSN 0340-6245. 


\section{Introduction}

Coronavirus disease of 2019 (COVID-19) is a respiratory illness caused by a novel coronavirus, severe acute respiratory syndrome coronavirus 2 (SARS-CoV-2). SARS-CoV-2 is an enveloped, positive-sense single-stranded ribonucleic acid virus belonging to the Coronaviridae family. ${ }^{1}$ The COVID-19 outbreak started in Wuhan, China, in late 2019 and rapidly spread to rest of the world. On March 11, 2020, the World Health Organization declared COVID-19 outbreak as pandemic. As of June 24, 2020, the global number of COVID-19 cases stood at 9.26 million with 478,000 deaths (Source: Johns Hopkins Coronavirus Resource Center, https://coronavirus.jhu.edu/). Disease course is markedly different between individuals while some are completely asymptomatic, others develop mild symptoms including mild fever, loss of taste or smell, dry cough, sore throat, shortness of breath, and myalgia. ${ }^{2-4}$ In susceptible individuals, the disease progresses to pneumonia, hypoxemia, acute respiratory distress, and multiorgan dysfunction that may lead to death. ${ }^{3}$ The predominance of asymptomatic or mild infections has contributed to the rapid spread of COVID-19 compared with earlier coronavirus outbreaks of SARS and Middle East respiratory syndrome in 2002 and 2012, respectively. ${ }^{4,5}$

\section{Consumptive Coagulopathy and the High Incidence of Thrombosis in COVID-19 Patients}

Altered coagulation is a common feature of acute systemic diseases, specifically to those affecting primarily the respiratory system. Based on studies in patients with acute respiratory distress syndrome (ARDS), the coexistence of disseminated intravascular coagulation (DIC) with subsequent consumption of procoagulation proteins and platelets has been consistently described. ${ }^{6}$ This in turn leads to the formation of microthrombi in the vascular bed of organs resulting from excess coagulation byproducts and suppression of endogenous anticoagulation factors. ${ }^{7}$ The coexistence of consumptive coagulopathy and thrombosis are the result of a common pathologic pathway; however, the exact mechanisms that tilts the balance toward thrombosis in COVID-19 are less well understood. ${ }^{8}$ In this sense, some features of the coagulopathy associated with COVID-19 may be not unique to this disease; however, the magnitude of the thrombotic response and its impact on mortality suggests the presence of additional mechanisms, beyond what is known for similar respiratory acute inflammatory diseases.

Several studies have linked coagulation abnormalities to severe COVID-19 illness ${ }^{9,10}$ (- Table 1). In a study evaluating 449 severe COVID-19 patients, Tang et al $^{11}$ reported positive correlation of 28-day mortality with fibrin degradation product (FDP), D-dimers and prothrombin time (PT), and negative correlation with platelet count. Laboratory parameters were recorded at the time of onset of severe COVID-19 in the study. In an earlier study comprising 183 patients, Tang et $\mathrm{l}^{12}$ reported elevated D-dimer levels and FDP levels and prolonged PT and activated partial thromboplastin times (aPTTs) at the time of admission in nonsurvivors compared with survivors. In the same study, significantly lower levels of fibrinogen and antithrombin levels were observed during the late hospitalization in nonsurvivors. Huang et $\mathrm{al}^{13}$ reported higher D-dimers and prolonged PT at the time of admission in intensive care unit (ICU) patients compared with non-ICU patients in a study of 41 patients. Wang et $\mathrm{al}^{14}$ reported elevated PT in a study of 138 patients. In the same study, elevated levels of D-dimers were found in ICU patients compared with non-ICU patients as well as in survivors compared with nonsurvivors in a subgroup of patients with a definitive outcome. In a study of 94 COVID-19 patients, Han et al $^{15}$ reported lower antithrombin and higher D-dimers, FDP, and fibrinogen levels compared with healthy controls. Zhou et $\mathrm{al}^{16}$ reported an association of elevated D-dimers with in-hospital death in a study of 191 patients. Also, elevated PT and decreased platelet counts were observed in nonsurvivors compared with survivors. Elevated levels of D-dimers were reported by Richardson et al ${ }^{17}$ among 5,700 patients in the New York City area. Ranucci et $\mathrm{al}^{18}$ reported a procoagulant profile in 16 patients characterized by increased clot strength by viscoelastography, elevated D-dimer levels, and hyperfibrinogenemia. A metaanalysis of 9 studies encompassing 1,779 patients with severe disease has identified significantly lower platelet counts. ${ }^{19}$ A subgroup analysis based on survival has identified even lower platelet counts in nonsurvivors in this study. Llitjos et $\mathrm{al}^{20}$ and Helms et $\mathrm{al}^{7}$ reported elevated D-dimer and fibrinogen levels in 26 and 150 ICU-admitted patients, respectively. Overall, elevated PT, increased D-dimer and fibrinogen levels, and thrombocytopenia are frequently reported in COVID-19 patients. However, bleeding events requiring therapeutic intervention are not reported.

Multiple studies have reported a higher incidence of thrombotic events, particularly pulmonary embolism, as a frequent complication in COVID-19 patients (-Table 1 ). Llitjos et $\mathrm{al}^{20}$ reported overall rate of $69 \%$ venous thromboembolism (VTE) in severe COVID-19 patients admitted to ICU. In this study, VTE incidence was found to be significantly higher in patients treated with prophylactic anticoagulation compared with those treated with therapeutic anticoagulation. Helms et $\mathrm{al}^{7}$ reported 64 clinically relevant thrombotic complications in 150 ICU-admitted patients. Importantly, the incidence of thrombotic complications in COVID-19 ARDS patients was significantly higher than non-COVID-19 ARDS patients in this study. Ackermann et $\mathrm{al}^{21}$ compared lung sections of COVID-19 patients with those died from ARDS secondary to influenza A (H1N1) infection and found relatively higher: (1) endothelial cell injury, (2) alveolar microthrombi (ninefold), and (3) intussusceptive angiogenesis in COVID-19 lung sections. Similarly, higher incidence of thromboembolic complications in ICU-admitted COVID-19 patients was also reported by Klok et al (31\%), ${ }^{22}$ Lodigiani et al (27.6\%), ${ }^{23}$ Middeldorp et al (47\%), ${ }^{24}$ Nahum et al (79\%), ${ }^{25}$ and Cui et al (25\%). ${ }^{26}$ For comparison, in a study by Zhang et al, the reported cumulative incidence of VTE in ICU-admitted patients receiving guideline-recommended thromboprophylaxis was $9.55 \%$ (95\% confidence interval: $6.55-13.81)^{27}$ 
Table 1 Studies (multiple patients) reporting abnormal coagulopathy in COVID-19

\begin{tabular}{|c|c|c|}
\hline Study & Type of study, number of patients & Findings/Significance \\
\hline \multicolumn{3}{|c|}{ Clinical features of COVID-19 patients, coagulation parameters included } \\
\hline Huang et $\mathrm{al}^{13}$ & Prospective, 41 patients & $\begin{array}{l}\text { Prothrombin time and D-dimer levels on admission } \\
\text { were higher in patients that required ICU treatment }\end{array}$ \\
\hline Zhou et al ${ }^{16}$ & Retrospective, 191 COVID-19 patients & $\begin{array}{l}\text { Increased D-dimer on admission is associated with } \\
\text { poor prognosis }\end{array}$ \\
\hline Guan et al ${ }^{44}$ & Retrospective, 1,099 COVID-19 patients & Thrombocytopenia in $36.2 \%$ \\
\hline Goyal et al ${ }^{36}$ & Retrospective, 393 COVID-19 patients & Thrombocytopenia in $27 \%$ \\
\hline Zhu et $\mathrm{al}^{45}$ & Meta-analysis & Elevated D-dimer in $\sim 37.2 \%$ of patients \\
\hline \multicolumn{3}{|c|}{ Studies on coagulation parameters } \\
\hline Ranucci et $a^{18}$ & Prospective, 16 ARDS COVID-19 patients & $\begin{array}{l}\text { Patients showed a procoagulant profile (clot } \\
\text { strength, platelet, fibrinogen, D-dimers, } \\
\text { hyperfibrinogenemia) }\end{array}$ \\
\hline Tang et al ${ }^{12}$ & Retrospective, 183 COVID-19 patients & $\begin{array}{l}\text { Nonsurvivors had significantly higher D-dimer and } \\
\text { fibrin degradation product (FDP) levels, longer } \\
\text { prothrombin time, and activated partial thrombo- } \\
\text { plastin time compared with survivors on admission. } \\
71.4 \% \text { of nonsurvivors and } 0.6 \% \text { survivors met the } \\
\text { criteria of DIC during their hospital stay }\end{array}$ \\
\hline Lippi et al ${ }^{19}$ & Meta-analysis & $\begin{array}{l}\text { Low platelet count associated with increased risk of } \\
\text { severe disease and mortality in patients with } \\
\text { COVID-19 }\end{array}$ \\
\hline Zhang et $\mathrm{al}^{29}$ & Retrospective, 343 COVID-19 patients & $\begin{array}{l}\text { Patients with D-dimer levels } \geq 2.0 \mu \mathrm{g} / \mathrm{mL} \text { had a } \\
\text { higher incidence of mortality when comparing to } \\
\text { those who with D-dimer levels }<2.0 \mu \mathrm{g} / \mathrm{mL}\end{array}$ \\
\hline Escher et al ${ }^{108,109}$ & $\begin{array}{l}\text { Case study, } 1 \text { patient and } 3 \text { more in the follow-up } \\
\text { publication }\end{array}$ & $\begin{array}{l}\text { Continual increase of D-dimers, elevated FVIII ac- } \\
\text { tivity, and normal platelet counts }\end{array}$ \\
\hline Bowles et $\mathrm{al}^{112}$ & $\begin{array}{l}216 \text { COVID-19 patients } \\
34 \text { tested for lupus anticoagulant }\end{array}$ & $\begin{array}{l}\text { 91\% of patients tested positive for lupus antico- } \\
\text { agulant. All lupus anticoagulant-positive specimens } \\
\text { had a prolonged aPTT. Increased aPTT should not } \\
\text { be a reason to withhold anticoagulation therapy }\end{array}$ \\
\hline Lorenzo-Villalba et al ${ }^{115}$ & Case reports, 3 patients & $\begin{array}{l}\text { Severe thrombocytopenia during COVID-19 infec- } \\
\text { tion associated with either cutaneous purpura or } \\
\text { mucosal bleeding }\end{array}$ \\
\hline Yin et al ${ }^{116}$ & $\begin{array}{l}\text { Retrospective, } 449 \text { COVID-19 and } 104 \text { non-COVID } \\
\text { severe pneumonia }\end{array}$ & $\begin{array}{l}\text { Patients with severe pneumonia induced by SARS- } \\
\text { CoV-2 had higher platelet count than those induced } \\
\text { by non-SARS-CoV-2. Patients infected by SARS-CoV- } \\
2 \text { may benefit from anticoagulant treatment, if } \\
\text { they have markedly elevated D-dimer }\end{array}$ \\
\hline Tabatabai et al ${ }^{48}$ & Case series, 10 patients & $\begin{array}{l}\text { Elevated FVIII activity and low normal antithrombin } \\
\text { and functional protein C activity }\end{array}$ \\
\hline \multicolumn{3}{|c|}{ Thrombosis in the COVID-19 patients } \\
\hline Middeldorp et $\mathrm{al}^{24}$ & Retrospective, 198 patients & $\begin{array}{l}\text { The cumulative incidences of VTE at } 7,14 \text {, and } \\
21 \text { days were } 16 \%, 33 \% \text {, and } 42 \% \text {, respectively. VTE } \\
\text { was higher in the ICU and was associated with } \\
\text { death }\end{array}$ \\
\hline Nahum et $\mathrm{al}^{25}$ & Prospective, 34 patients & $\begin{array}{l}\text { Deep vein thrombosis was found in } 22 \text { patients } \\
(65 \%) \text { at admission and in } 27 \text { patients ( } 79 \%) \text { when } \\
\text { the venous ultrasonograms performed } 48 \text { hours } \\
\text { after ICU admission were included. D-dimers and } \\
\text { fibrinogen were also increased }\end{array}$ \\
\hline Cui et $\mathrm{al}^{26}$ & Retrospective, 81 severe COVID-19 patients & $\begin{array}{l}\text { Incidence of VTE at } 25 \% \text {. D-dimer increase has a } \\
\text { predictive value }\end{array}$ \\
\hline Klok et $\mathrm{al}^{22}$ & Retrospective, 184 patients, no control group & $\begin{array}{l}31 \% \text { cumulative incidence of symptomatic acute } \\
\text { pulmonary embolism (PE), deep vein thrombosis, } \\
\text { ischemic stroke, myocardial infarction, or systemic } \\
\text { arterial embolism in COVID-19 patients }\end{array}$ \\
\hline
\end{tabular}


Table 1 (Continued)

\begin{tabular}{|c|c|c|}
\hline Study & Type of study, number of patients & Findings/Significance \\
\hline Zhang et $\mathrm{al}^{27}$ & Prospective, 281 ICU COVID-19 patients & $\begin{array}{l}\text { Cumulative incidence of VTE at } 28 \text { days was } 9.55 \% \text {, } \\
\text { despite all patients receiving thromboprophylaxis }\end{array}$ \\
\hline Demelo-Rodríguez et al ${ }^{117}$ & Prospective, 156 COVID-19 patients & $\begin{array}{l}\text { D-dimer levels }>1,570 \mathrm{ng} / \mathrm{mL} \text { were associated with } \\
\text { asymptomatic DVT }\end{array}$ \\
\hline Grandmaison et al ${ }^{118}$ & $\begin{array}{l}\text { Cross-sectional study, } 58 \text { COVID- } 19 \text { patients, } 29 \text { in } \\
\text { the ICU and } 29 \text { in the medicine ward }\end{array}$ & $\begin{array}{l}\text { In the ICU, VTEs were found in } 17 \text { (58.6\%) of the } 29 \\
\text { patients } \\
\text { In the medicine ward, VTEs were found in } 6(20.7 \%) \\
\text { patients }\end{array}$ \\
\hline Fraissé et al ${ }^{119}$ & Retrospective, 92 ICU COVID-19 patients & $\begin{array}{l}\text { High rate of thrombotic events (TEs) in ICU COVID- } \\
19 \text { patients highlighting the necessity for throm- } \\
\text { boprophylaxis and TE screening. Hemorrhagic } \\
\text { events (HEs) were also observed in patients on full- } \\
\text { dose anticoagulation }\end{array}$ \\
\hline Jian et al ${ }^{114}$ & Retrospective, 3,218 COVID-19 patients & $\begin{array}{l}\text { Acute stroke was the most common neuroimaging } \\
\text { finding, present in } 1.1 \% \text { of hospitalized COVID- } 19 \\
\text { patients }\end{array}$ \\
\hline Desborough et al ${ }^{121}$ & Retrospective, 66 patients & $\begin{array}{l}10 \text { patients had at least one proven episode of } \\
\text { thromboembolism. Major bleeding occurred in } \\
\text { seven cases }\end{array}$ \\
\hline Akel et al ${ }^{122}$ & Case reports, 6 patients & $\begin{array}{l}\text { Patients did not have any hypercoagulable risk } \\
\text { factors yet presented with pulmonary embolism }\end{array}$ \\
\hline Kashi et al ${ }^{123}$ & Case reports, 7 patients & Arterial thrombosis \\
\hline Lax et al ${ }^{124}$ & $\begin{array}{l}\text { Prospective autopsy study, } 11 \text { deceased COVID-19 } \\
\text { patients }\end{array}$ & $\begin{array}{l}\text { Death may be caused by the thrombosis observed } \\
\text { in segmental and subsegmental pulmonary arterial } \\
\text { vessels despite the use of prophylactic } \\
\text { anticoagulation }\end{array}$ \\
\hline Thomas et al ${ }^{125}$ & Retrospective, 63 COVID-19 patients & High thrombotic risk in patients with COVID-19 \\
\hline Gomez-Arbelaez et al ${ }^{126}$ & Case reports, 4 patients & $\begin{array}{l}\text { Aortic thrombosis and associated ischemic com- } \\
\text { plications in patients with severe SARS-CoV-2 } \\
\text { infection }\end{array}$ \\
\hline \multicolumn{3}{|c|}{ Anticoagulation treatment in COVID-19 patients } \\
\hline Tang et al ${ }^{11}$ & $\begin{array}{l}\text { Retrospective, } 449 \text { severe COVID-19 patients, } 99 \\
\text { received heparin }\end{array}$ & $\begin{array}{l}\text { Anticoagulant therapy is associated with better } \\
\text { prognosis in severe COVID- } 19 \text { patients with sepsis } \\
\text { induced coagulopathy or markedly elevated D- } \\
\text { dimer }\end{array}$ \\
\hline Wang et $\mathrm{al}^{28}$ & 3 case reports & $\begin{array}{l}\text { Treatment with tissue plasminogen activator lead } \\
\text { to improvement in the respiratory status }\end{array}$ \\
\hline Ayerbe et al ${ }^{127}$ & $\begin{array}{l}\text { 2,075 COVID-19 patients, admitted in } 17 \text { hospitals } \\
\text { in Spain }\end{array}$ & $\begin{array}{l}\text { Heparin had been used in } 1,734 \text { patients. Heparin } \\
\text { was associated with lower mortality }\end{array}$ \\
\hline Wang et $\mathrm{al}^{128}$ & Retrospective, 1,099 COVID-19 patients & $\begin{array}{l}\text { High risk of venous thromboembolism, also high } \\
\text { risk of bleeding }\end{array}$ \\
\hline Artifoni et al ${ }^{129}$ & Retrospective, 62 patients & $\begin{array}{l}16 \text { patients developed VTE, } 7 \text { patients developed } \\
\text { PE } \\
\text { Very high negative predictive value of baseline D- } \\
\text { dimer level for VTE and PE }\end{array}$ \\
\hline Russo et al $^{130}$ & Retrospective, 192 COVID-19 patients & $\begin{array}{l}\text { Preadmission antithrombotic therapy, both anti- } \\
\text { platelet and anticoagulant, does not seem to show } \\
\text { a protective effect in severe forms of COVID-19 } \\
\text { with ARDS at presentation and rapidly evolving } \\
\text { toward death }\end{array}$ \\
\hline \multicolumn{3}{|c|}{ Link between SARS-CoV-2 and thrombosis } \\
\hline Ackermann et $\mathrm{al}^{21}$ & $\begin{array}{l}7 \text { lung autopsies from COVID-19 patients and } 7 \\
\text { from ARDS }\end{array}$ & $\begin{array}{l}\text { Vascular angiogenesis distinguished the pulmo- } \\
\text { nary pathobiology of COVID-19 from that of equally } \\
\text { severe influenza virus infection }\end{array}$ \\
\hline Maier et al ${ }^{131}$ & $\begin{array}{l}\text { Case studies } \\
15 \text { COVID-19 patients with hyperviscosity }\end{array}$ & $\begin{array}{l}\text { Possible causal relationship between hyperviscosi- } \\
\text { ty and thrombotic complications in COVID- } 19\end{array}$ \\
\hline
\end{tabular}

(Continued) 
Table 1 (Continued)

\begin{tabular}{|l|l|l|}
\hline Study & Type of study, number of patients & Findings/Significance \\
\hline Huisman et al ${ }^{105}$ & 12 COVID-19 patients & $\begin{array}{l}\text { Low ADAMTS-13 activity, increased VWF levels and } \\
\text { factor VIII levels }\end{array}$ \\
\hline Galeano-Valle et al ${ }^{111}$ & Prospective study, 24 patients & $\begin{array}{l}\text { Prevalence of antiphospholipid antibodies in } \\
\text { COVID-19 and venous thrombosis was low }\end{array}$ \\
\hline Magro et al & Case reports, 5 severe COVID-19 cases & $\begin{array}{l}\text { Procoagulant state is associated with systemic } \\
\text { complement activation }\end{array}$ \\
\hline
\end{tabular}

Abbreviations: ADAMTS-13, a disintegrin and metalloproteinase with a thrombospondin type 1 motif, member 13; aPTT, activated partial thromboplastin time; ARDS, acute respiratory distress syndrome; COVID-19, coronavirus disease of 2019; DIC, disseminated intravascular coagulation; DVT, deep vein thrombosis; FVIII, factor VIII; ICU, intensive care unit; SARS-CoV-2, severe acute respiratory syndrome coronavirus 2; VTE, venous thromboembolism; VWF, von Willebrand factor.

A high incidence of DIC diagnosed by D-dimer, fibrinogen, and antithrombin III levels has become a focus for the initiation of anticoagulation therapy in severe COVID-19 patients, ${ }^{28}$ with some studies relying on D-dimers alone. ${ }^{11,29}$ A retrospective analysis of 183 patients performed by Tang et al $^{12}$ suggested that more than $70 \%$ of severe COVID-19 patients who succumb to the infection demonstrate increased risk of thrombosis, further this group suggests that all of these patients meet the International Society on Thrombosis and Haemostasis definition of DIC. Subsequently, Tang et al $^{11}$ reported an equivalent 28-day mortality rate (30\%) in 99 patients receiving low molecular weight or unfractionated heparin for 7 days compared with 350 nonheparin treated patients or those receiving a less than 7-day course of therapy. A case series reported by Wang et $\mathrm{al}^{28}$ detailed the use and outcome following tissue plasminogen activator (TPA) in three patients with ARDS and coagulopathy consistent with DIC. Intravenous dosing with TPA indicated a potential benefit in each of the three cases of COVID19. However, this study also warns of both unrelated effects and high risk of severe bleeding secondary to off-label tPA use. Several of the studies in coagulopathic COVID-19 patients suspected of DIC rely heavily on analysis of fibrin degradation and D-dimer levels, which are expected to be increased during DIC, arterial and venous thromboses, strokes, and thrombotic microangiopathies. ${ }^{30}$ However, D-dimers are a nonspecific indicator of thrombosis in severe COVID-19 patients with pulmonary injury. Fibrin accumulation and lysis continuously occur during nonthrombotic inflammation as well as tissue necrosis, and therefore, significant D-dimer elevations also accumulate during cancers ${ }^{31}$ and infections, consistent with inflammatory processes that coincide with the progression of severe COVID-19-related macrophage activation syndrome. ${ }^{32}$ Therefore, we suggest that more comprehensive and robust assays be used to evaluate changes in hemostasis. For example, to date the use of thrombin, plasmin, or simultaneous thrombin/plasmin generation assays have not been reported within the context of hemostasis management of COVID-19 patients. Since their introduction thrombin and plasmin generation assays have been highly informative regarding the assessment of hemorrhage, coagulation, and fibrinolysis. ${ }^{33,34}$ Assessment of impairment of these systems would provide a useful and appropriate guidance needed for and monitoring of therapeutic interventions in the unique coagulopathies associated with COVID-19. ${ }^{33,34}$ Because patients are often on unfractionated or low molecular weight heparin and plasminogen activator inhibitor 1, von Willebrand factor (VWF), plasminogen, fibrinogen, and factor VIII are all reported to be elevated in SARS infection, ${ }^{35}$ and therefore careful modification of these assays may be warranted to optimize the concentrations of added tPA, tissue factor, and thrombomodulin.

These studies present a heterogeneous picture that is difficult to evaluate in the aggregate. Inclusion criteria for patients varied across these studies, making direct comparisons between the studies difficult. Further, the studies used different regimens of thromboprophylaxis, which could impact outcomes. In some studies, a high proportion of patients were still hospitalized at the end of the reporting period; conclusions and clinical courses therefore were based on incomplete information, and completion of these patients' clinical course could alter the final conclusions. The picture of coagulopathy in COVID-19 is complex. Specific, sensitive, and temporal assessments of coagulation and fibrinolysis should be established and further work is needed to untangle the roles of the host inflammatory response, preexisting thrombotic risk, and prehospitalization pharmacologic regimens in the optimal management of coagulopathy in the setting of COVID-19.

\section{Inflammation, Liver Injury, and Hypoxia in COVID-19 Patients}

The risk of hospitalization, morbidity, and mortality from COVID-19 is highest for older patients with preexisting conditions such as hypertension, diabetes, cardiovascular disease, and obesity. ${ }^{13,14,16,17,36,37}$ A common theme of all these comorbidities is their association with vascular inflammation and endothelial dysfunction. ${ }^{38,39}$ Proinflammatory conditions affect hemostasis by blocking of fibrinolysis and induction of prothrombotic conditions through activation of endothelial cells and innate immune cells via release of several factors including tissue factor, $\mathrm{VWF}$, and neutrophil extracellular traps (NETs) that promote thrombosis. ${ }^{40}$ Induction of proinflammatory conditions was reported in the pathophysiology of several viral diseases including influenza and SARS. ${ }^{41}$ Increased inflammation is commonly observed in COVID-19 patients, while severe cases are characterized by immune dysregulation and hyperinflammation, with a markedly increased serum interleukin (IL)-6. ${ }^{42}$ Cytokine release syndrome has also been reported in COVID-19 patients and correlates with adverse 
Table 2 Studies reporting elevated inflammatory markers in COVID-19

\begin{tabular}{|c|c|c|}
\hline Study & Patient group (number of patients) comparison & Elevated inflammatory markers \\
\hline Huang et $\mathrm{al}^{13}$ & ICU (13) vs. non-ICU (28) & 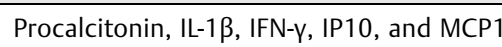 \\
\hline Wang et al ${ }^{14}$ & ICU (36) vs. non-ICU (102) & Procalcitonin \\
\hline Zhou et al ${ }^{16}$ & Nonsurvivor (54) vs. survivor (137) & Procalcitonin, ferritin, and IL-6 \\
\hline Richardson et al ${ }^{17}$ & Relative to reference range (3066) & Procalcitonin, ferritin, and CRP \\
\hline Ruan et $\mathrm{al}^{37}$ & Nonsurvivor (68) vs. survivor (82) & CRP and IL-6 \\
\hline Giamarellos-Bourboulis et $\mathrm{al}^{42}$ & $\begin{array}{l}\text { Dysregulated ( } 21) \text { vs. intermediate state } \\
\text { (26) of immune activation }\end{array}$ & CRP and IL-6 \\
\hline Chen et al ${ }^{47}$ & Severe $(\geq 9)$ vs. moderate $(\geq 7)$ & CRP, ferritin, IL-6, and TNF- $\alpha$ \\
\hline Han et $\mathrm{al}^{49}$ & COVID-19 patients (102) vs. controls (45) & CRP, IL-6, TNF- $\alpha$, and IFN- $\gamma$ \\
\hline Du et al ${ }^{50}$ & $\begin{array}{l}\text { Mild pneumonia (124) vs. no pneumonia } \\
\text { (54) (pediatric patients) }\end{array}$ & Procalcitonin, IL-6, TNF- $\alpha$, and IFN- $\gamma$ \\
\hline Wang et $\mathrm{al}^{52}$ & $\begin{array}{l}\mathrm{SpO}_{2} \geq 90 \%(\geq 36) \text { vs. } \\
\mathrm{SpO}_{2}<90 \%(\geq 7)\end{array}$ & CRP and IL-6 \\
\hline Tan et $\mathrm{al}^{53}$ & Severe (25) vs. mild/moderate 31) & CRP and IL-6 \\
\hline Tabatabai et al ${ }^{48}$ & Relative to reference range (10) & Fibrinogen, CRP, and ferritin \\
\hline
\end{tabular}

Abbreviations: COVID-19, coronavirus disease of 2019; CRP, C-reactive protein; ICU, intensive care unit; IFN- $\gamma$, interferon-ү; IL-1 1 , interleukin-1 $\beta$; IL-6, Interluekin6; IP-10, interferon-y induced protein 10; MCP-1, monocyte chemotactic protein-1; $\mathrm{SpO}_{2}$, blood oxygen saturation level; TNF- $\alpha$, tumor necrosis factor- $\alpha$.

clinical outcomes. ${ }^{43}$ The presence of several inflammatory markers such as C-reactive protein, procalcitonin, ferritin, and fibrinogen are often reported in COVID-19 patients $^{13,14,16,17,36,37,44-48}$ (- Table 2). Further, multiple studies reported elevated levels of the proinflammatory cytokine IL6 in severe cases of COVID-19 16,37,42,47,49-53 (- Table 2). A concurrent increase in the levels of anti-inflammatory cytokine IL-10, probably in response to overwhelming systemic inflammation, was also observed in several studies. The role of IL-6, in particular, is considered central in the pathogenesis of COVID19 complications, ${ }^{54}$ and therefore tocilizumab, an IL-6 inhibitor, is being used in ongoing clinical trials to prevent catastrophic inflammation. ${ }^{55-58}$

Liver injury during COVID-19 infections was described in multiple studies, including elevated levels of alanine aminotransferase, aspartate aminotransferase, and bilirubin. ${ }^{14,16,17,36,44,47}$ The liver is the primary source of plasma proteins, particularly those involved in hemostasis. Thus, the occurrence of liver injury may contribute further to derangements of key hemostasis proteins and contributes to coagulopathy. ${ }^{59}$ Similarly, hypoxemia observed in COVID-19 patients induces prothrombotic conditions through upregulation of plasminogen activator inhibitor and stimulation of endothelial synthesis of procoagulants, including tissue factor and VWF. $^{60-63}$ Thus, multiple clinical characteristics observed in COVID-19 patients contribute to altered coagulation and lead to increased incidence of thrombosis. However, the early onset of coagulopathy-before systemic organic effects occur-suggests proinflammatory conditions as the primary driving cause of thrombotic events in COVID-19 patients.

\section{VWF-ADAMTS-13 in Hemostasis and Thrombosis}

VWF and its cleaving protease, a disintegrin and metalloproteinase with a thrombospondin type 1 motif, member
13 (ADAMTS-13), play an important role in hemostasis particularly within the microvasculature. ${ }^{64}$ VWF is a large multimeric glycoprotein primarily expressed by endothelial cells and platelets. Endothelial cells show both basal secretion and regulated release of VWF stored in Weibel-Palade bodies in response to various stimuli. On the other hand, platelets secrete VWF stored in $\alpha$-granules only upon activation. ${ }^{65}$ ADAMTS-13 is expressed both by hepatic stellate cells and endothelial cells; the relative contribution of hepatic and microvascular expression is not clear. ${ }^{66}$ ADAMTS-13 regulates the biological activity of VWF by cleaving prothrombotic ultra-large VWF multimers ( $>10,000 \mathrm{kDa}$ ) secreted from endothelial cells into hemostatically active high molecular weight multimers $(<10,000 \mathrm{kDa})$ under shear stress conditions. ${ }^{67}$ Severe deficiency of ADAMTS-13 results in accumulation of ultra-large VWF multimers leading to microvascular thrombosis and consumptive thrombocytopenia, a condition termed thrombotic thrombocytopenic purpura (TTP). ${ }^{64}$ In the event of vascular injury, VWF facilitates binding of platelets to subendothelium through its interactions with glycoprotein $\mathrm{Ib}$ and collagen, thereby inducing thrombus formation. ${ }^{64} \mathrm{~A}$ reciprocal relationship exists between VWF and ADAMTS-13 levels where elevated circulatory VWF antigen levels are associated with concomitant decrease in ADAMTS-13 activity and vice versa. ${ }^{68-70}$ Abnormal VWF-ADAMTS-13 ratios are implicated in arterial thrombosis, ${ }^{71}$ ischemic stroke, ${ }^{72,73}$ pediatric stroke, ${ }^{74}$ and perioperative thrombosis in infants. ${ }^{75}$ In addition, abnormal VWF/ADAMTS-13 metabolism has been positively associated with myocardial infarction in young women. ${ }^{76}$ It is worth highlighting that in the case of perioperative thrombosis, elevated VWF even in the absence of significant deficiency of ADAMTS-13 was associated with thrombosis. ${ }^{75}$ Severe hypoxia and acidosis likely caused a higher increase in VWF during cardiac surgery and were at higher risk of thrombosis. $^{75}$ 
Elevated levels of VWF are found in several inflammatory and metabolic disorders including diabetes, obesity, and sickle cell disease. ${ }^{77}$ In patients with systemic inflammatory response syndrome, active VWF predicted 28-day mortality. ${ }^{78} \mathrm{VWF}$ is an acute-phase response protein released by activated endothelial cells in response to inflammatory stimuli. ${ }^{77}$ Inflammatory cytokines, IL- 8 and tumor necrosis factor- $\alpha$ induced the release of VWF from human umbilical vein endothelial cells. ${ }^{79} \mathrm{VWF}$ released in inflammation binds to NETs released from activated neutrophils and recruits platelets and leukocytes to promote thrombosis. ${ }^{77}$ ADAMTS-13 deficiency in inflammatory conditions was demonstrated to promote VWF-dependent leukocyte adhesion and extravasation in mice. ${ }^{80}$

In patients with systemic inflammation, ADAMTS- 13 activity decreases proportional to the inflammatory response; an imbalance between ADAMTS-13 activity and VWF antigen is associated with organ dysfunction and death. ${ }^{81,82}$ Dysregulated host response to infection including inflammation can result in septic shock. In septic shock, ADAMTS-13 activity was significantly lower ${ }^{83-85}$ and elevated ratio of VWF propeptide (VWFpp) that is secreted along with ultra-large VWF multimers in to blood stream and ADAMTS-13 was associated with disease severity. ${ }^{86}$ In patients with DIC, ADAMTS-13 activity decreased with DIC score $^{87}$ and VWFpp/ADAMTS-13 ratio was significantly elevated in nonsurvivors compared with survivors. ${ }^{88}$ An interesting observation is that smoking, which is associated with adverse outcomes in COVID-19 patients, ${ }^{89}$ was also found to be associated with decreased plasma ADAMTS-13 levels in a study of 3,244 individuals. ${ }^{90}$ Increased expression of angiotensin-converting enzyme 2 , the entry receptor for SARS-CoV-2, in the small airway epithelia of smokers was suggested as the potential mechanism for increased risk of severe COVID-19 in smokers. ${ }^{91}$ Smoking is also associated with increased inflammatory markers. ${ }^{92}$

The imbalance between ADAMTS-13 and VWF in heightened inflammation could be a result of inhibition and/or deficiency of ADAMTS-13 activity. ${ }^{93}$ The inhibition of VWF cleavage by ADAMTS-13 in inflammatory conditions was suggested to be mediated by several mechanisms: (1) thrombospondin-1 released from $\alpha$-granules of activated platelets by binding to the A2-A3 domain of $\mathrm{VWF}^{94,95}$; (2) $\alpha$-defensins released from neutrophils by binding to the $\mathrm{A} 2$ domain of $\mathrm{VWF}^{96}$; and (3) oxidation of Met 1606 residue in the ADAMTS-13 cleavage site of VWF. ${ }^{97}$ Moreover, nonphysiological high concentrations of IL-6 have been shown to inhibit cleavage of VWF by ADAMTS-13 in vitro under shear flow conditions. ${ }^{79}$ Granulocyte elastases, plasmin, and thrombin that are elevated in inflammatory conditions lower ADAMTS-13 activity through its proteolytic cleavage. ${ }^{98,99}$

\section{VWF-ADAMTS-13 Interactions in COVID-19}

Despite playing an important role in the maintenance of hemostasis and the occurrence of micro- and macrovascular thrombosis, VWF-ADAMTS-13 interactions have not received much investigative attention in the evaluation of COVID-19 pathophysiology, specifically in relation to elevated incidence of VTE. Importantly, reduced ADAMTS-13 activity has been shown to correlate with increased inflammation in multiple sys- tems, ${ }^{100-102}$ while IL- 6 has been shown to inhibit the cleavage of ultra-large VWF strings by ADAMTS-13 under flowing conditions. ${ }^{79,103}$ The authors could find only five studies evaluating both VWF and ADAMTS-13 levels in COVID-19 patients in literature ${ }^{104-108}$ ( - Table 3). Majority of these studies reported lower ADAMTS-13 activity concurrent with higher VWF in COVID-19 patients. ${ }^{104-107}$ In one of these studies, Bazzan et al $^{104}$ reported lower ADAMTS-13 levels in 88 COVID-19 patients compared with healthy controls $(48.71 \pm 18.7 \%$ vs. healthy control, $108 \pm 9.1 \%$; normal value $60-130 \%$ ). Within patient cohort, lower ADAMTS-13 and higher VWF levels were found in nonsurvivors (9/88) compared with survivors. Further, lower than 30\% ADAMTS-13 activity were significantly associated with mortality in survivor analysis. Huisman et al ${ }^{105}$ observed low ADAMTS-13 activity levels $(0.48 \pm 0.14 \mathrm{IU} / \mathrm{mL}$ against a reference range of $0.61-1.31$ ) in parallel with elevated VWF antigen and activity ( $\sim$ fourfold) in 12 ICU-admitted patients. A similar reduction in ADAMTS-13 and increased VWF levels was also reported by Adam et al ${ }^{106}$ and Latimer et $\mathrm{al}^{107}$ in 4 adult and 1 pediatric patients, respectively. On the other hand, Escher et $\mathrm{al}^{108}$ observed normal to lower-normal ADAMTS-13 levels concurrently with $>2.5$-fold increase in VWF antigen and activity in 3 ICU-admitted patients. Two other studies ${ }^{7,109}$ reported VWF measurements alone, observing $>$ threefold increase in both VWF antigen and activity. From the limited number of studies so far, it appears that COVID-19 infection may be characterized by markedly elevated VWF levels and below normal ADAMTS-13 activity. However, the current literature is limited by the small number of studies and variable timing of VWF/ADAMTS-13 measurements in relation to disease onset. Further evaluation of VWF and ADAMTS- 13 interactions in large patient cohorts are warranted to more confidently understand their contributions to COVID-19 pathogenesis.

A secondary mechanism potentially contributing to ADAMTS-13 deficiency relates to the antiphospholipid antibody generation during SARS-CoV-2 infection. ${ }^{7,110-112}$ Antiphospholipid antibodies have been inconsistently reported in all cases of COVID 19, $7,111,112$ but strongly associated to prolong aPTT as reported by Bowles et al. ${ }^{12}$ Patients with antiphospholipid syndrome have been found to have abnormal ADAMTS-13 plasmatic activity further increasing the risk of thrombosis. ${ }^{113}$ The exact mechanisms by which antiphospholipid antibodies interfere with ADAMTS-13 cleaving activity are unclear. We speculate that antiphospholipid antibodies generated during active SARS-CoV-2 infection can potentially bind the spacer domain of ADAMTS-13 interfering with the recognition and proteolysis of VWF. Such a mechanism is similar to the binding of autoantibodies against ADAMTS-13 present in TTP resulting in clinical thrombosis. ${ }^{114}$

Based on the limited available data, we propose a mechanistic model in which: (1) SARS-CoV-2 causes endothelial activation and damage leading to overwhelming VWF release and (2) proinflammatory mediators or antibodies during the severe phase of COVID-19 result in reduced cleavage of high molecular weight VWF by ADAMTS-13, ultimately leading to thrombosis, see - Fig. 1. This concept should be confirmed by large patient cohorts that encompass mild and severe clinical courses of COVID-19 disease. A mechanistic understanding of thrombosis 
Table 3 Studies reporting ADAMTS-13 and VWF levels in COVID-19

\begin{tabular}{|c|c|c|}
\hline Study & Patient group (number of patients) comparison & Findings/Significance \\
\hline Bazzan et al ${ }^{104}$ & Nonsurvivor (9) vs. survivor (79) & $\begin{array}{l}\text { Lower ADAMTS- } 13 \text { and elevated VWF levels in nonsurvivors } \\
\text { compared with survivors. After survival analysis, lower than } 30 \% \\
\text { ADAMTS-13 levels were significantly associated with higher mortality }\end{array}$ \\
\hline Huisman et al ${ }^{105}$ & Relative to reference range (12) & Lower ADAMTS-13 and elevated VWF levels \\
\hline Adam et al ${ }^{106}$ & Relative to reference range (4) & Lower ADAMTS-13 and elevated VWF levels \\
\hline Latimer et al $^{107}$ & $\begin{array}{l}\text { Relative to reference range } \\
\text { (1 pediatric patient) }\end{array}$ & Lower ADAMTS-13 and elevated VWF levels \\
\hline Escher et al ${ }^{108,109}$ & $\begin{array}{l}\text { Case study, } 1 \text { patient and } \\
3 \text { more in the follow-up } \\
\text { publication }\end{array}$ & $\begin{array}{l}\text { Massive elevation of VWF and normal to lower-normal ADAMTS- } 13 \\
\text { activity. COVID-19 coagulopathy may be a distinct entity of highly } \\
\text { prothrombotic alterations most probably an endothelial disease }\end{array}$ \\
\hline Helms et $\mathrm{al}^{7}$ & $\begin{array}{l}\text { Relative to reference } \\
\text { range (150) }\end{array}$ & Elevated VWF levels \\
\hline
\end{tabular}

Abbreviations: ADAMTS-13, a disintegrin and metalloproteinase with a thrombospondin type 1 motif, member 13; COVID-19, coronavirus disease of 2019; VWF, von Willebrand factor.

\section{A] Hemostasis}
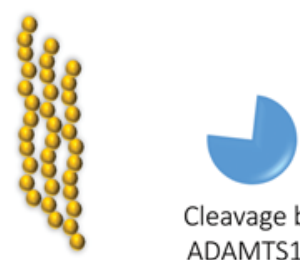

Cleavage by

VWF

ADAMTS13

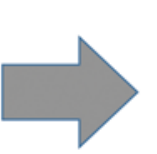

B] Inflammation

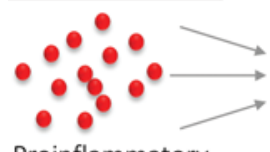

Proinflammatory cytokines

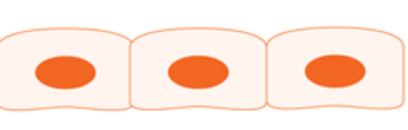

Endothelial cells
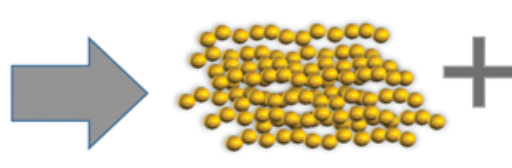

Excessive release of VWF

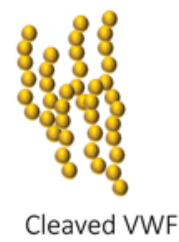

Neutrophil extracellular traps

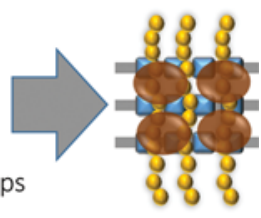

Thrombus

\section{C] Cleavage of VWF by ADAMTS13 is prevented by the following mechanisms}

1) Binding of thrombospondin-1 released from $\alpha$-granules of activated platelets to A2-A3 domain of VWF harboring the proteolytic cleavage site of ADAMTS13

2) Binding of $\alpha$-defensins released from neutrophils to A2 domain of VWF

3) Oxidation of Met 1606 residue in the ADAMTS13 cleavage site of VWF by reactive oxygen species

4) High concentrations of IL-6

5) Proteolytic cleavage of ADAMTS13 by granulocyte elastases, plasmin, and thrombin that are elevated in inflammatory conditions

Fig. 1 von Willebrand factor (VWF)-a disintegrin and metalloproteinase with a thrombospondin type 1 motif, member 13 (ADAMTS-13) metabolism in inflammation. (A) During normal homeostasis, ADAMTS-13 regulates the activity of VWF by cleaving prothrombotic ultra-large VWF multimers released from endothelial cells in to hemostatically active high molecular weight multimers. (B) In inflammatory disorders, proinflammatory cytokines (e.g., interleukin [IL]-8 and tumor necrosis factor [TNF]- $\alpha$ ) stimulate excess release of VWF stored in Weibel-Palade bodies of endothelial cells. VWF interacts with neutrophil extracellular traps (NETs) released from neutrophils to provide a scaffold for platelet adhesion and thrombus formation. (C) In inflammation, cleavage of VWF by ADAMT-S13 is prevented by multiple mechanisms that either inhibit or reduce the proteolytic activity of ADAMTS- 13 .

during COVID-19 infection is greatly needed to better guide thromboprophylaxis and treatment. The extent to which VWFADAMTS-13 interactions contribute to the pathophysiology of COVID-19 should be an important investigative focus.

\section{Funding}

This work was partly supported by funds from the Hemostasis Branch/Division of Plasma Protein Therapeutics/ Office of Tissues and Advanced Therapies/Center for Biologics Evaluation and Research of the U.S. Food and Drug Administration. This research was also supported by the Intramural Research Program of the National Library of Medicine at the NIH.

\section{Conflict of interest}

None declared.

\section{References}

1 Lu R, Zhao X, Li J, et al. Genomic characterisation and epidemiology of 2019 novel coronavirus: implications for virus origins and receptor binding. Lancet 2020;395(10224):565-574

2 Epidemiology Working Group for NCIP Epidemic Response, Chinese Center for Disease Control and Prevention. The epidemiological characteristics of an outbreak of 2019 novel coronavirus diseases (COVID-19) in China [in Chinese]. Zhonghua Liu Xing Bing Xue Za Zhi 2020;41(02):145-151

3 Singhal T. A review of coronavirus disease-2019 (COVID-19). Indian J Pediatr 2020;87(04):281-286 
4 Rothe C, Schunk M, Sothmann P, et al. Transmission of 2019$\mathrm{nCoV}$ infection from an asymptomatic contact in Germany. N Engl J Med 2020;382(10):970-971

5 Petrosillo N, Viceconte G, Ergonul O, Ippolito G, Petersen E. COVID-19, SARS and MERS: are they closely related? Clin Microbiol Infect 2020;26(06):729-734

6 Gando S, Fujishima S, Saitoh DJapanese Association for Acute Medicine (JAAM) Focused Outcomes Research in Emergency Care in Acute Respiratory Distress Syndrome, Sepsis and Trauma (FORECAST) Study Group, et al; The significance of disseminated intravascular coagulation on multiple organ dysfunction during the early stage of acute respiratory distress syndrome. Thromb Res 2020;191:15-21

7 Helms J, Tacquard C, Severac FCRICS TRIGGERSEP Group (Clinical Research in Intensive Care and Sepsis Trial Group for Global Evaluation and Research in Sepsis), et al; High risk of thrombosis in patients with severe SARS-CoV-2 infection: a multicenter prospective cohort study. Intensive Care Med 2020;46(06): 1089-1098

8 Boral BM, Williams DJ, Boral LI. Disseminated intravascular coagulation. Am J Clin Pathol 2016;146(06):670-680

9 Willyard C. Coronavirus blood-clot mystery intensifies. Nature 2020;581(7808):250

10 Thachil J, Tang N, Gando S, et al. ISTH interim guidance on recognition and management of coagulopathy in COVID-19. J Thromb Haemost 2020;18(05):1023-1026

11 Tang N, Bai H, Chen X, Gong J, Li D, Sun Z. Anticoagulant treatment is associated with decreased mortality in severe coronavirus disease 2019 patients with coagulopathy. J Thromb Haemost 2020;18(05):1094-1099

12 Tang N, Li D, Wang X, Sun Z. Abnormal coagulation parameters are associated with poor prognosis in patients with novel coronavirus pneumonia. J Thromb Haemost 2020;18(04): 844-847

13 Huang C, Wang Y, Li X, et al. Clinical features of patients infected with 2019 novel coronavirus in Wuhan, China. Lancet 2020;395 (10223):497-506

14 Wang D, Hu B, Hu C, et al. Clinical characteristics of 138 hospitalized patients with 2019 novel coronavirus-infected pneumonia in Wuhan, China. JAMA 2020;323(11):1061-1069

15 Han H, Yang L, Liu R, et al. Prominent changes in blood coagulation of patients with SARS-CoV-2 infection. Clin Chem Lab Med 2020;58(07):1116-1120

16 Zhou F, Yu T, Du R, et al. Clinical course and risk factors for mortality of adult inpatients with COVID-19 in Wuhan, China: a retrospective cohort study. Lancet 2020;395(10229):1054-1062

17 Richardson S, Hirsch JS, Narasimhan Mand the Northwell COVID19 Research Consortium, et al; Presenting characteristics, comorbidities, and outcomes among 5700 patients hospitalized with COVID-19 in the New York City area. JAMA 2020;323(20): 2052-2059

18 Ranucci M, Ballotta A, Di Dedda U, et al. The procoagulant pattern of patients with COVID-19 acute respiratory distress syndrome. J Thromb Haemost 2020;18(07):1747-1751

19 Lippi G, Plebani M, Henry BM. Thrombocytopenia is associated with severe coronavirus disease 2019 (COVID-19) infections: a meta-analysis. Clin Chim Acta 2020;506:145-148

20 Llitjos JF, Leclerc M, Chochois C, et al. High incidence of venous thromboembolic events in anticoagulated severe COVID-19 patients. J Thromb Haemost 2020;18(07):1743-1746

21 Ackermann M, Verleden SE, Kuehnel M, et al. Pulmonary vascular endothelialitis, thrombosis, and angiogenesis in Covid-19. N Engl J Med 2020;383(02):120-128

22 Klok FA, Kruip MJHA, van der Meer NJM, et al. Incidence of thrombotic complications in critically ill ICU patients with COVID-19. Thromb Res 2020;191:145-147

23 Lodigiani C, Iapichino G, Carenzo LHumanitas COVID-19 Task Force, et al; Venous and arterial thromboembolic complications in COVID-19 patients admitted to an academic hospital in Milan, Italy. Thromb Res 2020;191:9-14

24 Middeldorp S, Coppens M, van Haaps TF, et al. Incidence of venous thromboembolism in hospitalized patients with COVID19. J Thromb Haemost 2020

25 Nahum J, Morichau-Beauchant T, Daviaud F, et al. Venous thrombosis among critically ill patients with coronavirus disease 2019 (COVID-19). JAMA Netw Open 2020;3(05):e2010478

26 Cui S, Chen S, Li X, Liu S, Wang F. Prevalence of venous thromboembolism in patients with severe novel coronavirus pneumonia. J Thromb Haemost 2020;18(06):1421-1424

27 Zhang C, Zhang Z, Mi J, et al. The cumulative venous thromboembolism incidence and risk factors in intensive care patients receiving the guideline-recommended thromboprophylaxis. Medicine (Baltimore) 2019;98(23):e15833

28 Wang J, Hajizadeh N, Moore EE, et al. Tissue plasminogen activator (tPA) treatment for COVID-19 associated acute respiratory distress syndrome (ARDS): a case series. J Thromb Haemost 2020;18(07):1752-1755

29 Zhang L, Yan X, Fan Q et al. D-dimer levels on admission to predict in-hospital mortality in patients with Covid-19. J Thromb Haemost 2020;18(06):1324-1329

30 Urban K, Kirley K, Stevermer JJ. PURLs: it's time to use an agebased approach to D-dimer. J Fam Pract 2014;63(03):155-158

31 Schäfer M, Werner S. Cancer as an overhealing wound: an old hypothesis revisited. Nat Rev Mol Cell Biol 2008;9(08):628-638

32 Merad M, Martin JC. Pathological inflammation in patients with COVID-19: a key role for monocytes and macrophages. Nat Rev Immunol 2020;20(06):355-362

33 Hemker HC, Giesen P, Al Dieri R, et al. Calibrated automated thrombin generation measurement in clotting plasma. Pathophysiol Haemost Thromb 2003;33(01):4-15

34 Simpson ML, Goldenberg NA, Jacobson LJ, Bombardier CG, Hathaway WE, Manco-Johnson MJ. Simultaneous thrombin and plasmin generation capacities in normal and abnormal states of coagulation and fibrinolysis in children and adults. Thromb Res 2011;127(04):317-323

$35 \mathrm{Wu}$ YP, Wei R, Liu ZH, et al. Analysis of thrombotic factors in severe acute respiratory syndrome (SARS) patients. Thromb Haemost 2006;96(01):100-101

36 Goyal P, Choi JJ, Pinheiro LC, et al. Clinical characteristics of Covid-19 in New York City. N Engl J Med 2020;382(24): 2372-2374

37 Ruan Q Yang K, Wang W, Jiang L, Song J. Clinical predictors of mortality due to COVID-19 based on an analysis of data of 150 patients from Wuhan, China. Intensive Care Med 2020;46(05): 846-848

38 Petrie JR, Guzik TJ, Touyz RM. Diabetes, hypertension, and cardiovascular disease: clinical insights and vascular mechanisms. Can J Cardiol 2018;34(05):575-584

39 Milan-Mattos JC, Anibal FF, Perseguini NM, et al. Effects of natural aging and gender on pro-inflammatory markers. Braz J Med Biol Res 2019;52(09):e8392

40 Engelmann B, Massberg S. Thrombosis as an intravascular effector of innate immunity. Nat Rev Immunol 2013;13(01):34-45

41 Jamilloux Y, Henry T, Belot A, et al. Should we stimulate or suppress immune responses in COVID-19? Cytokine and anticytokine interventions. Autoimmun Rev 2020;19(07):102567

42 Giamarellos-Bourboulis EJ, Netea MG, Rovina N, et al. Complex immune dysregulation in COVID-19 patients with severe respiratory failure. Cell Host Microbe 2020;27(06):992-1000.e3

43 Zhang C, Wu Z, Li JW, Zhao H, Wang GQ. Cytokine release syndrome in severe COVID-19: interleukin-6 receptor antagonist tocilizumab may be the key to reduce mortality. Int J Antimicrob Agents 2020;55(05):105954

44 Guan WJ, Ni ZY, Hu YChina Medical Treatment Expert Group for Covid-19, et al; Clinical characteristics of coronavirus disease 2019 in China. N Engl J Med 2020;382(18):1708-1720 
45 Zhu J, Ji P, Pang J, et al. . Clinical characteristics of 3,062 COVID-19 patients: a meta-analysis. J Med Virol 2020. Doi: 10.1002/jmv. 25884

46 Connors JM, Levy JH. COVID-19 and its implications for thrombosis and anticoagulation. Blood 2020;135(23):2033-2040

47 Chen G, Wu D, Guo W, et al. Clinical and immunological features of severe and moderate coronavirus disease 2019. J Clin Invest 2020;130(05):2620-2629

48 Tabatabai A, Rabin J, Menaker J, et al. Factor VIII and functional protein $C$ activity in critically ill patients with coronavirus disease 2019: a case series. A A Pract 2020;14(07):e01236

49 Han H, Ma Q, Li C, et al. Profiling serum cytokines in COVID-19 patients reveals IL-6 and IL-10 are disease severity predictors. Emerg Microbes Infect 2020;9(01):1123-1130

50 Du H, Dong X, Zhang JJ, et al. Clinical characteristics of 182 pediatric COVID-19 patients with different severities and allergic status. Allergy 2020

51 Liu J, Li S, Liu J, et al. Longitudinal characteristics of lymphocyte responses and cytokine profiles in the peripheral blood of SARS-CoV-2 infected patients. EBioMedicine 2020;55:102763

52 Wang Z, Yang B, Li Q, Wen L, Zhang R. Clinical features of 69 cases with coronavirus disease 2019 in Wuhan, China. Clin Infect Dis 2020: ciaa272

53 Tan M, Liu Y, Zhou R, et al. Immunopathological characteristics of coronavirus disease 2019 cases in Guangzhou, China. Immunology 2020;160(03):261-268

54 Chen X, Zhao B, Qu Y, et al. Detectable serum SARS-CoV-2 viral load (RNAaemia) is closely correlated with drastically elevated interleukin 6 (IL-6) level in critically ill COVID-19 patients. Clin Infect Dis 2020:ciaa449

55 Tocilizumab in COVID-19 Pneumonia (TOCIVID-19). Available at: https://ClinicalTrials.gov/show/NCT04317092. Accessed July 29, 2020

56 Tocilizumab for Prevention of Respiratory Failure in Patients With Severe COVID-19 Infection. Available at: https://ClinicalTrials.gov/show/NCT04377659. Accessed July 29, 2020

57 Efficacy of Early Administration of Tocilizumab in COVID-19 Patients. Available at: https://ClinicalTrials.gov/show/NCT04346355. Accessed July 29, 2020

58 Tocilizumab in the Treatment of Coronavirus Induced Disease (COVID-19). Available at: https://ClinicalTrials.gov/show/ NCT04335071. Accessed July 29, 2020

59 Premkumar M, Saxena P, Rangegowda D, et al. Coagulation failure is associated with bleeding events and clinical outcome during systemic inflammatory response and sepsis in acute-onchronic liver failure: an observational cohort study. Liver Int 2019;39(04):694-704

60 Mojiri A, Nakhaii-Nejad M, Phan WL, et al. Hypoxia results in upregulation and de novo activation of von Willebrand factor expression in lung endothelial cells. Arterioscler Thromb Vasc Biol 2013;33(06):1329-1338

61 Matsuura Y, Yamashita A, Iwakiri T, et al. Vascular wall hypoxia promotes arterial thrombus formation via augmentation of vascular thrombogenicity. Thromb Haemost 2015;114(01): 158-172

62 Ogawa S, Clauss M, Kuwabara K, et al. Hypoxia induces endothelial cell synthesis of membrane-associated proteins. Proc Natl Acad Sci U S A 1991;88(21):9897-9901

63 Fearns C, Loskutoff DJ. Induction of plasminogen activator inhibitor 1 gene expression in murine liver by lipopolysaccharide. Cellular localization and role of endogenous tumor necrosis factor-alpha. Am J Pathol 1997;150(02):579-590

64 Katneni UK, Ibla JC, Hunt R, Schiller T, Kimchi-Sarfaty C. von Willebrand factor/ADAMTS-13 interactions at birth: implications for thrombosis in the neonatal period. J Thromb Haemost 2019;17(03):429-440

65 Bryckaert M, Rosa JP, Denis CV, Lenting PJ. Of von Willebrand factor and platelets. Cell Mol Life Sci 2015;72(02):307-326
66 Zheng XL. ADAMTS13 and von Willebrand factor in thrombotic thrombocytopenic purpura. Annu Rev Med 2015;66:211-225

67 Stockschlaeder M, Schneppenheim R, Budde U. Update on von Willebrand factor multimers: focus on high-molecular-weight multimers and their role in hemostasis. Blood Coagul Fibrinolysis 2014;25(03):206-216

68 Mannucci PM, Capoferri C, Canciani MT. Plasma levels of von Willebrand factor regulate ADAMTS-13, its major cleaving protease. Br J Haematol 2004;126(02):213-218

69 Reiter RA, Knöbl P, Varadi K, Turecek PL. Changes in von Willebrand factor-cleaving protease (ADAMTS13) activity after infusion of desmopressin. Blood 2003;101(03):946-948

70 Reiter RA, Varadi K, Turecek PL, Jilma B, Knöbl P. Changes in ADAMTS13 (von-Willebrand-factor-cleaving protease) activity after induced release of von Willebrand factor during acute systemic inflammation. Thromb Haemost 2005;93(03):554558

71 Sonneveld MA, de Maat MP, Leebeek FW. Von Willebrand factor and ADAMTS13 in arterial thrombosis: a systematic review and meta-analysis. Blood Rev 2014;28(04):167-178

72 Bongers TN, de Maat MP, van Goor ML, et al. High von Willebrand factor levels increase the risk of first ischemic stroke: influence of ADAMTS13, inflammation, and genetic variability. Stroke 2006;37(11):2672-2677

73 Sonneveld MA, de Maat MP, Portegies ML, et al. Low ADAMTS13 activity is associated with an increased risk of ischemic stroke. Blood 2015;126(25):2739-2746

74 Lambers M, Goldenberg NA, Kenet G, et al. Role of reduced ADAMTS13 in arterial ischemic stroke: a pediatric cohort study. Ann Neurol 2013;73(01):58-64

75 Hunt R, Hoffman CM, Emani S, et al. Elevated preoperative von Willebrand factor is associated with perioperative thrombosis in infants and neonates with congenital heart disease. J Thromb Haemost 2017;15(12):2306-2316

76 Andersson HM, Siegerink B, Luken BM, et al. High VWF, low ADAMTS13, and oral contraceptives increase the risk of ischemic stroke and myocardial infarction in young women. Blood 2012; 119(06):1555-1560

77 Gragnano F, Sperlongano S, Golia E, et al. The role of von Willebrand factor in vascular inflammation: from pathogenesis to targeted therapy. Mediators Inflamm 2017;2017:5620314

78 Hyseni A, Kemperman H, de Lange DW, Kesecioglu J, de Groot PG, Roest M. Active von Willebrand factor predicts 28-day mortality in patients with systemic inflammatory response syndrome. Blood 2014;123(14):2153-2156

79 Bernardo A, Ball C, Nolasco L, Moake JF, Dong JF. Effects of inflammatory cytokines on the release and cleavage of the endothelial cell-derived ultralarge von Willebrand factor multimers under flow. Blood 2004;104(01):100-106

80 Chauhan AK, Kisucka J, Brill A, Walsh MT, Scheiflinger F, Wagner DD. ADAMTS13: a new link between thrombosis and inflammation. J Exp Med 2008;205(09):2065-2074

81 Bockmeyer CL, Claus RA, Budde U, et al. Inflammation-associated ADAMTS13 deficiency promotes formation of ultra-large von Willebrand factor. Haematologica 2008;93(01):137-140

82 Reuken PA, Kussmann A, Kiehntopf M, et al. Imbalance of von Willebrand factor and its cleaving protease ADAMTS13 during systemic inflammation superimposed on advanced cirrhosis. Liver Int 2015;35(01):37-45

83 Kremer Hovinga JA, Zeerleder S, Kessler P, et al. ADAMTS-13, von Willebrand factor and related parameters in severe sepsis and septic shock. J Thromb Haemost 2007;5(11):2284-2290

84 Bongers TN, Emonts M, de Maat MP, et al. Reduced ADAMTS13 in children with severe meningococcal sepsis is associated with severity and outcome. Thromb Haemost 2010;103(06):1181-1187

85 Karim F, Adil SN, Afaq B, Ul Haq A. Deficiency of ADAMTS-13 in pediatric patients with severe sepsis and impact on in-hospital mortality. BMC Pediatr 2013;13(01):44 
86 Fukushima H, Nishio K, Asai H, et al. Ratio of von Willebrand factor propeptide to ADAMTS13 is associated with severity of sepsis. Shock 2013;39(05):409-414

87 Hyun J, Kim HK, Kim JE, et al. Correlation between plasma activity of ADAMTS-13 and coagulopathy, and prognosis in disseminated intravascular coagulation. Thromb Res 2009;124 (01):75-79

88 Habe $\mathrm{K}$, Wada $\mathrm{H}$, Ito-Habe $\mathrm{N}$, et al. Plasma ADAMTS13, von Willebrand factor (VWF) and VWF propeptide profiles in patients with DIC and related diseases. Thromb Res 2012;129 (05):598-602

89 Vardavas CI, Nikitara K. COVID-19 and smoking: a systematic review of the evidence. Tob Induc Dis 2020;18:20

90 Ma Q Jacobi PM, Emmer BT, et al. Genetic variants in ADAMTS13 as well as smoking are major determinants of plasma ADAMTS13 levels. Blood Adv 2017;1(15):1037-1046

91 Leung JM, Yang CX, Tam A, et al. ACE-2 expression in the small airway epithelia of smokers and COPD patients: implications for COVID-19. Eur Respir J 2020;55(05):2000688

92 Barigye O. Smoking and inflammation. PLoS Med 2005;2(06):e198

93 Schwameis M, Schörgenhofer C, Assinger A, Steiner MM, Jilma B. VWF excess and ADAMTS13 deficiency: a unifying pathomechanism linking inflammation to thrombosis in DIC, malaria, and TTP. Thromb Haemost 2015;113(04):708-718

94 Wang A, Liu F, Dong N, et al. Thrombospondin-1 and ADAMTS13 competitively bind to VWF A2 and A3 domains in vitro. Thromb Res 2010;126(04):e260-e265

95 Bonnefoy A, Daenens K, Feys HB, et al. Thrombospondin-1 controls vascular platelet recruitment and thrombus adherence in mice by protecting (sub)endothelial VWF from cleavage by ADAMTS13. Blood 2006;107(03):955-964

96 Pillai VG, Bao J, Zander CB, et al. Human neutrophil peptides inhibit cleavage of von Willebrand factor by ADAMTS13: a potential link of inflammation to TTP. Blood 2016;128(01):110-119

97 Chen J, Fu X, Wang Y, et al. Oxidative modification of von Willebrand factor by neutrophil oxidants inhibits its cleavage by ADAMTS13. Blood 2010;115(03):706-712

98 Crawley JT, Lam JK, Rance JB, Mollica LR, O’Donnell JS, Lane DA. Proteolytic inactivation of ADAMTS13 by thrombin and plasmin. Blood 2005;105(03):1085-1093

99 OnoT, Mimuro J, Madoiwa S, et al. Severe secondary deficiency of von Willebrand factor-cleaving protease (ADAMTS13) in patients with sepsis-induced disseminated intravascular coagulation: its correlation with development of renal failure. Blood 2006;107 (02):528-534

100 Liu C, Zhao L, Zhao J, Xu Q Song Y, Wang H. Reduced ADAMTS-13 level negatively correlates with inflammation factors in plasma of acute myeloid leukemia patients. Leuk Res 2017;53:57-64

101 Takaya H, Kawaratani H, Kubo T, et al. Platelet hyperaggregability is associated with decreased ADAMTS13 activity and enhanced endotoxemia in patients with acute cholangitis. Hepatol Res 2018;48(03):E52-E60

102 Takaya H, Yoshiji H, Kawaratani H, et al. Decreased activity of plasma ADAMTS13 are related to enhanced cytokinemia and endotoxemia in patients with acute liver failure. Biomed Rep 2017;7(03):277-285

103 Chen J, Chung DW. Inflammation, von Willebrand factor, and ADAMTS13. Blood 2018;132(02):141-147

104 Bazzan M, Montaruli B, Sciascia S, Cosseddu D, Norbiato C, Roccatello D. Low ADAMTS 13 plasma levels are predictors of mortality in COVID-19 patients. Intern Emerg Med 2020

105 Huisman A, Beun R, Sikma M, Westerink J, Kusadasi N. Involvement of ADAMTS13 and von Willebrand factor in thromboembolic events in patients infected with SARS-CoV-2. Int J Lab Hematol 2020

106 Adam EH, Zacharowski K, Miesbach W. A comprehensive assessment of the coagulation profile in critically ill COVID-19 patients. Thromb Res 2020;194:42-44
107 Latimer G, Corriveau C, DeBiasi RL, et al. Cardiac dysfunction and thrombocytopenia-associated multiple organ failure inflammation phenotype in a severe paediatric case of COVID-19. Lancet Child Adolesc Health 2020;4(07):552-554

108 Escher R, Breakey N, Lämmle B. ADAMTS13 activity, von Willebrand factor, factor VIII and D-dimers in COVID-19 inpatients. Thromb Res 2020;192:174-175

109 Escher R, Breakey N, Lämmle B. Severe COVID-19 infection associated with endothelial activation. Thromb Res 2020;190:62

110 Lee SJ, Kim JE, Han KS, Kim HK. Thrombotic risk of reduced ADAMTS13 activity in patients with antiphospholipid antibodies. Blood Coagul Fibrinolysis 2016;27(08):907-912

111 Galeano-Valle F, Oblitas CM, Ferreiro-Mazón MM, et al. Antiphospholipid antibodies are not elevated in patients with severe COVID-19 pneumonia and venous thromboembolism. Thromb Res 2020;192:113-115

112 Bowles L, Platton S, Yartey N, et al. Lupus anticoagulant and abnormal coagulation tests in patients with Covid-19. N Engl J Med 2020;383(03):288-290

113 Austin SK, Starke RD, Lawrie AS, Cohen H, Machin SJ, Mackie IJ. The VWF/ADAMTS13 axis in the antiphospholipid syndrome: ADAMTS13 antibodies and ADAMTS13 dysfunction. Br J Haematol 2008;141(04):536-544

114 Jian C, Xiao J, Gong L, et al. Gain-of-function ADAMTS13 variants that are resistant to autoantibodies against ADAMTS13 in patients with acquired thrombotic thrombocytopenic purpura. Blood 2012;119(16):3836-3843

115 Lorenzo-Villalba N, Zulfiqar AA, Auburtin M, et al. Thrombocytopenia in the course of COVID-19 infection. Eur J Case Rep Intern Med 2020;7(06):001702

116 Yin S, Huang M, Li D, Tang N. Difference of coagulation features between severe pneumonia induced by SARS-CoV2 and nonSARS-CoV2. J Thromb Thrombolysis 2020. Doi: 10.1007/s11239020-02105-8

117 Demelo-Rodríguez P, Cervilla-Muñoz E, Ordieres-Ortega L, et al. Incidence of asymptomatic deep vein thrombosis in patients with COVID-19 pneumonia and elevated D-dimer levels. Thromb Res 2020;192:23-26

118 Grandmaison G, Andrey A, Périard D, et al. Systematic screening for venous thromboembolic events in COVID-19 pneumonia. TH Open 2020;4(02):e113-e115

119 Fraissé M, Logre E, Pajot O, Mentec H, Plantefève G, Contou D. Thrombotic and hemorrhagic events in critically ill COVID-19 patients: a French monocenter retrospective study. Crit Care 2020;24(01):275

120 Bastiani G, Valle MT. Determination of factor XII in blood products and correction of its deficiency after plasma transfusion in a case [in Italian]. Haematologica 1979;64(05): 635-640

121 Desborough MJR, Doyle AJ, Griffiths A, Retter A, Breen KA, Hunt $B J$. Image-proven thromboembolism in patients with severe COVID-19 in a tertiary critical care unit in the United Kingdom. Thromb Res 2020;193:1-4

122 Akel T, Qaqa F, Abuarqoub A, Shamoon F. Pulmonary embolism: a complication of COVID 19 infection. Thromb Res 2020; 193:79-82

123 Kashi M, Jacquin A, Dakhil B, et al. Severe arterial thrombosis associated with Covid-19 infection. Thromb Res 2020;192: 75-77

124 Lax SF, Skok K, Zechner P, et al. . Pulmonary arterial thrombosis in COVID-19 with fatal outcome: results from a prospective, singlecenter, clinicopathologic case series. Ann Intern Med 2020;173 (05):350-361

125 Thomas W, Varley J, Johnston A, et al. Thrombotic complications of patients admitted to intensive care with COVID-19 at a teaching hospital in the United Kingdom. Thromb Res 2020;191:76-77

126 Gomez-Arbelaez D, Ibarra-Sanchez G, Garcia-Gutierrez A, Comanges-Yeboles A, Ansuategui-Vicente M, Gonzalez-Fajardo 
JA. COVID-19-related aortic thrombosis: a report of four cases. Ann Vasc Surg 2020:S0890-5096(20)30438-6

127 Ayerbe L, Risco C, Ayis S. The association between treatment with heparin and survival in patients with Covid-19. J Thromb Thrombolysis 2020;50(02):298-301

128 Wang T, Chen R, Liu C, et al. Attention should be paid to venous thromboembolism prophylaxis in the management of COVID-19. Lancet Haematol 2020;7(05):e362-e363

129 Artifoni M, Danic G, Gautier G, et al. Systematic assessment of venous thromboembolism in COVID-19 patients receiving thromboprophylaxis: incidence and role of D-dimer as predictive factors. J Thromb Thrombolysis 2020;50(01):211-216
130 Russo V, Di Maio M, Attena E, et al. Clinical impact of preadmission antithrombotic therapy in hospitalized patients with COVID-19: a multicenter observational study. Pharmacol Res 2020;159:104965

131 Maier CL, Truong AD, Auld SC, Polly DM, Tanksley CL, Duncan A. COVID-19-associated hyperviscosity: a link between inflammation and thrombophilia? Lancet 2020;395(10239):1758-1759

132 Magro C, Mulvey JJ, Berlin D, et al. Complement associated microvascular injury and thrombosis in the pathogenesis of severe COVID-19 infection: a report of five cases. Transl Res 2020;220:1-13 